\title{
Pre-service Turkish Teachers' Metaphorical Perceptions Regarding the Concepts of "Instructional Technology" and "Teaching Material"
}

\author{
Başak Karakoç Öztürk*, B. Erdem Dağıstanlıoğlu \\ Department of Turkish Language Education, Faculty of Education, Çukurova University, Turkey
}

Copyright $@ 2018$ by authors, all rights reserved. Authors agree that this article remains permanently open access under the terms of the Creative Commons Attribution License 4.0 International License

\begin{abstract}
In this study, it was aimed to determine the perceptions of pre-service Turkish teachers (PTT) regarding the concepts of instructional technology and teaching material through metaphors. Within the scope of this aim, what the metaphors used by PTTs for the concepts of instructional technology and teaching material were and under which categories the metaphors used by them for these concepts were collected were investigated. The phenomenology design, one of the qualitative research methods, was used in the study. Data were collected from a total of 152 PTTs studying in the first, second, third and fourth grades of Çukurova University Faculty of Education Turkish Education Department. Data were collected by means of a form intended for completing the statements of "Instructional technology is like......... because.........." and "Teaching material is like ......... because......" and analyzed using the content analysis technique. As a result of the study, the metaphors examined for the concept of instructional technology were collected in 9 categories while the metaphors for the concept of teaching material were collected in 5 categories. The categories for instructional technology are informative/information source, tool/vehicle, requirement, permanence, change, attractiveness, process, development, and limitlessness, and the categories for teaching material are tool/vehicle, requirement, informative/information source, attractiveness and permanence.
\end{abstract}

Keywords Instructional Technology, Teaching Material, Metaphor, Pre-service Turkish Teacher

\section{Introduction}

The rapid change in science and technology has been reflected in education and has influenced the characteristics that should be present in people of our age, and teacher qualifications. The role of the teacher, which is defined as the absolute transmitter of information, has changed, and the role of teaching how to learn and guiding students to investigating, using technology and producing information has begun to be emphasized. Along with the fact that this different point of view has been reflected in teacher education, the requirement that teachers should integrate lessons with technology has emerged.

Teacher education is a complex whole involving the features such as content, method, material, aim, place and time [1]. Teachers state that they have important duties in organizing the educational environment and putting it into students' service and that it is necessary to have some critical skills and attributes to fulfill these duties successfully [2]. Although teacher qualifications can be defined differently, the common factor is the fact that teachers produce and use materials to activate teaching [3]. Davis [4] stated that the application of information and communication technologies in teacher education would help society to be equipped with the human qualities needed by it.

In Turkey, in 1998, teacher education was reorganized and the faculties of education were restructured; for this purpose, the "Instructional Technologies and Material Development" course became one of the compulsory courses in teacher training programs. The Council of Higher Education has defined the Instructional Technologies and Material Development course as the features of various instructional technologies, and their place and use in the teaching process, the development of teaching materials through instructional technologies (worksheets, transparencies, slides, video-based course materials, etc.), and the evaluation of materials with various qualities [5]. Therefore, pre-service teachers taking this course are aimed to be able to use technology in their courses, to design teaching processes more effectively and to acquire the teaching material development skill. The name of the course was then changed as Instructional Technologies and Material Design.

The use of technology and material in language teaching is of vital importance in the creation of an effective 
teaching environment and in the concretization of language elements that are an abstraction. The use of materials in language teaching provides many benefits for language learners such as gaining ability to understand the target language, developing the emphasis and intonation in the pronunciation of words, gaining an ability to use an appropriate expression for the situation, performing reading and writing practices, and developing measurement tools for language skills (listening comprehension, pronunciation, speaking, reading and writing tests) [6]. In this context, it is obvious that the Instructional Technologies and Material Design course will make significant contributions to PTTs in terms of enriching the language teaching process. Two basic concepts that come to the forefront within the scope of this course are instructional technology and teaching material. These concepts are extremely important and need to be internalized in terms of the Instructional Technologies and Material Design course and teacher training process.

Many definitions have been made for the concept of instructional technology, and different understandings have come to the forefront in these definitions. If attention is paid to the development of the definition of instructional technology from the 1900s to the 1960s, it appears that instructional technology was defined as a tool in these years and was considered as a method between 1960 and 1970. According to Reiser, the emphasis on "design and learning" instead of the emphasis on "tool" is a significant milestone [cited by 2]. Reiser [8] defines instructional technology as "The systematic design, implementation, and evaluation of the entire learning and teaching process in terms of specific objectives by using human and material resources together, based on investigations related to learning and communication to provide more effective teaching". Seels and Richey [9] made the most popular definition in the field and defined instructional technology as the theory and application of designing, developing, using, managing and evaluating the processes and resources for learning. The teaching material generally includes the contents of course presentations performed using tools to achieve the objectives. Tools are needed to create a material. A blackboard is a tool. It becomes a course material when an operation, picture, graphic, text, etc. is created on it with chalk or a board marker [10]. Although the determination of how the concepts of instructional technology and teaching material are perceived by PTTs is worthwhile in terms of determining whether the philosophy of the course has been understood or not, it is also important since it has an enlightening characteristic about to what extent pre-service teachers have internalized these concepts. One of the important ways of determining the perception of PTTs regarding the concepts of instructional technology and teaching material is to use metaphors that are among the strongest cognitive tools. According to Lakoff, the metaphor is a usual way, a basic and compulsory part of the conceptualization of the world by a human [11]. The metaphor is a structure that enables us to understand abstract concepts and to think abstractly [11]. Kövecses [12] defined the metaphor as "the understanding of a conceptual field in terms of another conceptual field". These two conceptual fields have special names. The field that provides the understanding of a conceptual field with metaphorical expressions is the "source field", and the field understood by this way is the "target field". Therefore, the conceptual metaphor can be briefly described as the fact that "the conceptual field $\mathrm{A}$ is the conceptual field B". According to Lakoff \& Johnson [13], the metaphor is one of the most important tools that enable a partial understanding of the aspects of a human such as the feelings that are not fully understood, aesthetic experiences, ethical practices and spiritual awareness. Metaphors make it easier for students to learn concepts and to keep them in mind. Furthermore, metaphors improve students' creative and scientific thinking and problem-solving skills [14]. Experts use metaphors as a way of explaining complex meanings and defining implicit and indirect processes [15]. Clandinin [16] stated that metaphors could be used as the indicators of teachers' opinions about teaching and as a guide of their behaviors in the classroom. Moreover, metaphors are an important part of teachers' personal information including the ways they perceive their roles as teachers $[16,17]$. The metaphor analysis is also useful for the discovery of social and cultural processes of understanding and for accessing implicit knowledge [18].

Metaphors are the tools with a characteristic of reflecting individuals' feelings as well as their cognitive structures such as thoughts and beliefs about facts and events [19]. In this context, it was thought that the findings obtained within the scope of the study would have significant consequences in terms of teacher education that metaphors would provide information about what PTTs think, believe and feel with regard to the concepts of instructional technology and teaching material, and that teacher education would be reviewed accordingly. Upon examining the relevant literature, it was determined that metaphor analyses were performed for the concept of technology with different study groups $[20,21,22,23,24$, $25]$, that there were studies focusing on educational technology [26, 27], that studies examining the metaphors for the concepts of the internet [28], Facebook [29] and social media [30] were carried out; however, there was no metaphor study for the concept of instructional technology. It was also determined that no independent study was carried out for the concept of teaching material and that only the factorial structures formed by metaphors related to the concepts of the teacher, teaching, learning, teaching material, and evaluation were examined by Eren and Tekinarslan [31]. Therefore, by taking into consideration the relevant studies, it was thought that there was a need for a holistic study in which the concepts of instructional technology and teaching material are analyzed through metaphors. It was thought that the study carried out in this regard would contribute to the development of teacher 
training programs and the relevant literature.

\section{The Aim of the Study}

In this study, it was aimed to determine the perceptions of PTTs regarding the concepts of instructional technology and teaching material through metaphors. Within the scope of this aim, it was sought to answer the following questions:

- What are the metaphors used by PTTs for the concept of instructional technology?

- Under which categories can the metaphors used by PTTs for the concept of instructional technology be collected?

- What are the metaphors used by PTTs for the concept of teaching material?

- Under which categories can the metaphors used by PTTs for the concept of teaching material be collected?

\section{Method}

\subsection{Research Model}

The phenomenology design, one of the qualitative research methods, was used in the study. Facts appear in various forms such as events, experiences, perceptions, orientations, concepts, and situations. The phenomenology design provides a suitable research ground for studies aimed at investigating the facts we are not entirely unfamiliar with but at the same time the full meaning of which we cannot grasp [32]. Furthermore, phenomenology is appropriate to investigate the facts about which people do not have in-depth information or cannot fully comprehend [33,34].

\subsection{Study Group}

The criteria sampling method, one of the purposeful sampling methods, was used in the selection of the study group, and it was aimed to collect data from PTTs studying in all grade levels of Çukurova University Faculty of Education Turkish Education Department. In this context, data were collected from a total of 152 PTTs studying in the first, second, third and fourth grades during the 2017-2018 spring term. However, 2 PTTs who did not explain the metaphor they wrote were not included in the study group.

The personal information of the study group is presented in Table 1.

\begin{tabular}{cccc}
\multicolumn{5}{c}{ Table 1. Characteristics of the Study Group } \\
\hline \multirow{3}{*}{ Gender } & & f & \% \\
\cline { 2 - 4 } & Male & 67 & 44.67 \\
& Female & 83 & 55.33 \\
\cline { 2 - 4 } Grade & Total & $\mathbf{1 5 0}$ & $\mathbf{1 0 0}$ \\
& $1^{\text {st }}$ Grade & 30 & 20 \\
& $2^{\text {nd }}$ Grade & 36 & 24 \\
& $3^{\text {rd }}$ Grade & 43 & 28.67 \\
& $4^{\text {th }}$ Grade & 41 & 27.33 \\
\hline
\end{tabular}

As it is seen in Table 1,67 of PTTs constituting the study group were male, 83 of them were female. On the other hand, when PTTs are examined in terms of grade levels, it is observed that 30 of them are in the first grade, 36 of them are in the second grade, 43 of them are in the third grade, and 41 of them are in the fourth grade.

\subsection{Data Collection}

In the data collection process, explanatory information related to the metaphor and exemplary information for the metaphor were primarily given to PTTs, and then a form in which they were asked to complete the statements of "Instructional technology is like.......... because.........." and "Teaching material is like ......... because......." was distributed to determine their perceptions regarding the concepts of instructional technology and teaching material. PTTs were given 30 minutes, and data were obtained by filling out the form in writing.

In the studies in which metaphors are used as a research tool, the concept of "like" is generally used to connotate the relationship between "the subject of the metaphor" and "the source of the metaphor" more clearly [35]. By including the concept of "Because", participants are asked to present a reason or logical basis for their own metaphors [36].

\subsection{Data Analysis}

The collected data were analyzed using the content analysis technique, one of the qualitative data analysis techniques. The analysis process was performed in four stages including coding and sorting stage, sample metaphor compilation stage, category development stage, and the stage of ensuring validity and reliability $[33,36]$.

In the coding and sorting stage, the metaphors produced by PTTs were listed in alphabetical order, and whether they clearly expressed a particular metaphor was examined. Then, the metaphor indicated by each PTT was coded. 2 forms in which the metaphor written was not explained by reason were excluded from evaluation.

In the sample metaphor compilation stage, 150 valid metaphors obtained after the sorted metaphors were rearranged in alphabetical order, and each form was coded as PTT1, PTT2, etc. Then, the sample metaphor statement that best represented each metaphor was selected. Thus, the sample metaphor list was created. This list was used while deciding under which categories metaphors would be collected.

In the category creation stage, the metaphors produced by PTTs both for instructional technology and teaching material were examined in terms of common characteristics. 94 different metaphors for the concept of instructional technology and 82 different metaphors for teaching material were analyzed in terms of the subject of the metaphor, the source of the metaphor, and the relationship between the subject and source of the metaphor. While the metaphors examined for the concept 
of instructional technology were collected in 9 categories in terms of their common characteristics, the metaphors for the concept of teaching material were collected in 5 categories.

\subsection{Validity and Reliability}

The most important criteria of ensuring validity in qualitative research are the detailed reporting of the data collected and the fact that the researcher explains how he/she has reached the conclusions [32]. In this study, the analysis process of the data was explained in detail and the metaphors and categories determined were included in the results section.

To ensure reliability, the metaphors in the forms written by PTTs and the possible categories for metaphors were listed, and both researchers performed classification with respect to which category was appropriate for the metaphors at different times. The analyses performed by the researchers were compared, and the cases when there were dissensus and consensus were determined. In this context, Miles and Huberman's [37] formula (Reliability = consensus / consensus + dissensus X 100) was used, and it was determined that the percentage of agreement between the researchers was $98 \%$ (147 consensus and 3 dissensus) for instructional technology and $98.6 \%$ (148 consensus and 2 dissensus) for teaching material.

\section{Findings}

\subsection{Findings for the Concept of Instructional Technology}

The metaphors produced by PTTs for instructional technology were examined in terms of having positive and negative qualities in terms of meaning, and the results are presented in Table 2.

Table 2. Distribution of the Metaphors of PPTs for the Concept of Instructional Technology

\begin{tabular}{|c|c|c|c|c|c|}
\hline \multirow[t]{2}{*}{ Category } & \multicolumn{4}{|c|}{ Name of Metaphor } & \multirow[t]{2}{*}{ Total } \\
\hline & Water (11) & Compass (2) & Water channel & Computer & \\
\hline & Lantern (10) & Guide (2) & Antifreeze & Chameleon & \\
\hline & Book (7) & Food processor (2) & An hour and minute hand & Crossword & \\
\hline & Road (6) & Means of transport (2) & Academician & Refrigerator & \\
\hline & Pencil (4) & Remote control (2) & Smartphone & Blood & \\
\hline & Tree (3) & Hair straightener & Mobile phone & Heart & \\
\hline & Pole Star (2) & Tool kit & Air conditioner & Tractor & \\
\hline & Time (2) & Clothes peg & Bridge & Television & \\
\hline & Brain (2) & A leaf of a flower & Mineral water & Nail & \\
\hline & Mother (2) & Shoe & Skeleton key & Seed & \\
\hline & Friend (2) & Spice & Ink & Sea & \\
\hline \multirow[t]{12}{*}{ POSITIVE METAPHORS } & Salt (2) & Honeycomb & Walking stick & Child & 148 \\
\hline & Plane (2) & Lodestar & Car & Teacher & \\
\hline & Appetizer (2) & Lighthouse & Moon & Baby & \\
\hline & Love & Body language & Public transportation vehicles & Gear & \\
\hline & Flower (2) & Head of the body & Tribune drum & Chain & \\
\hline & Chocolate (2) & Galaxy & Vitamin & Drug & \\
\hline & Soil (2) & Ship & Limbs of the body & Universe & \\
\hline & Hand (2) & Rainbow & Artificial intelligence robot & Right arm & \\
\hline & Human (2) & Glasses & Jigsaw piece & Ivy & \\
\hline & Sun (2) & Rope & Plaster & Map & \\
\hline & Air (2) & Chess pieces & Auxiliary robots & Dictionary & \\
\hline & Stairs (2) & Swedish pocketknife & Meal & Rhyme & \\
\hline NEGATIVE MET APHORS & \multicolumn{2}{|c|}{$\begin{array}{l}\text { Teachers depended on ready-made } \\
\text { material }\end{array}$} & \multicolumn{2}{|l|}{ Slide } & 2 \\
\hline Total & & & & & 150 \\
\hline
\end{tabular}


As it is seen in Table 2, it was determined that 148 (99\%) of 150 PTTs used metaphors with positive connotations in terms of meaning for the concept of instructional technology, and only 2 PTTs produced metaphors that could be considered as negative. When the metaphors that were described as positive were examined, it was determined that the most commonly used metaphors were water (11), lantern (10), book (7), road (6) and pencil (4). The examples of metaphors with positive meaning are as follows:

"Instructional technology is like water because it is the basis and source of life, we cannot give up." (PTT 39)

"Instructional technology is like a lantern because you can know the direction on the road illuminated by it." (PTT 29)

"Instructional technology is like a book because it allows us to access information." (PTT 121)

"Instructional technology is like a road because it enables to achieve the objective." (PTT 149)

"Instructional technology is like a pencil because you will not forget what you have written." (РTT 2)
One of the PTTs who produced a negative metaphor wrote the statement of "Instructional technology is like a teacher depended on ready-made material because he gives the same thing every year, he does not renew himself." (PTT 27). The other one used a negative metaphor by stating that "Instructional technology is like a slide because the teacher always tells the same without changing it." (PTT 58).

As it is seen in Table 3, 9 categories emerged for the concept of instructional technology. These categories are informative/information source, tool/vehicle, requirement, permanence, change, attractiveness, process, development, and limitlessness. It is observed that PTTs mostly produced metaphors regarding the informative/information source category for instructional technology. It was followed by the tool / vehicle and requirement categories. When the metaphors evaluated under the informative/information source category were examined, it was determined that PTTs most commonly used the lantern (10) metaphor and it was followed by the book (4), road (3), mother (2), pole star (2), sun (2), friend (2), guide (2) and compass (2) metaphors.

Table 3. Distribution of the Metaphors of PTTS for Instructional Technology by Categories

\begin{tabular}{|c|c|c|c|c|c|c|}
\hline Category & & & etaphor & & $\mathbf{f}$ & $\%$ \\
\hline \multirow{5}{*}{$\begin{array}{c}\text { Informative/Information } \\
\text { Source }\end{array}$} & Lantern (10) & Sun (2) & Academician & Moon & \multirow{5}{*}{40} & \multirow{5}{*}{26.67} \\
\hline & Book (4) & Friend (2) & Head of the body & Dictionary & & \\
\hline & Road (3) & Guide (2) & Teacher & Soil & & \\
\hline & Mother (2) & Compass (2) & Lighthouse & Crossword & & \\
\hline & Pole Star (2) & Lodestar & Flower & Map & & \\
\hline \multirow{7}{*}{ Tool/Vehicle } & Remote control (2) & Car & Air conditioner & Honeycomb & \multirow{7}{*}{32} & \multirow{7}{*}{21.33} \\
\hline & Means of transport (2) & Smartphone & Water channel & Mineral water & & \\
\hline & Food processor (2) & Glasses & Artificial intelligence robot & Tool kit & & \\
\hline & Plane (2) & Antifreeze & Hair straightener & Ship & & \\
\hline & Walking stick & Plaster & Swedish pocketknife & Tractor & & \\
\hline & Stairs & Gear & Auxiliary robots & Shoe & & \\
\hline & Skeleton key & Chess piece & Public transportation vehicles & Bridge & & \\
\hline \multirow{5}{*}{ Requirement } & Water (11) & Salt (2) & An hour and minute hand & Meal & \multirow{5}{*}{32} & \multirow{5}{*}{21.33} \\
\hline & Air (2) & Heart & Computer & Drug & & \\
\hline & Hand (2) & Right arm & A leaf of a flower & Blood & & \\
\hline & Chocolate (2) & Spice & Limbs of the body & Vitamin & & \\
\hline & Brain (2) & & & & & \\
\hline \multirow{3}{*}{ Permanence } & Pencil (4) & Nail & Refrigerator & Television & \multirow{3}{*}{16} & \multirow{3}{*}{10.67} \\
\hline & Book (3) & Jigsaw piece & Ink & Rhyme & & \\
\hline & Clothes peg & Ivy & Body language & & & \\
\hline \multirow[t]{2}{*}{ Change } & Time (2) & Galaxy & $\begin{array}{l}\text { Teachers depended on } \\
\text { ready-made material }\end{array}$ & Chameleon & \multirow[t]{2}{*}{8} & \multirow[t]{2}{*}{5.33} \\
\hline & Tree & Slide & Mobile phone & & & \\
\hline \multirow{2}{*}{ Attractiveness } & Appetizer (2) & Rainbow & Tribune drum & Rope & \multirow{2}{*}{7} & \multirow{2}{*}{4.67} \\
\hline & Love & Flower & & & & \\
\hline \multirow{2}{*}{ Process } & Road (3) & Tree & Soil & Chain & \multirow{2}{*}{7} & \multirow{2}{*}{4.67} \\
\hline & Stairs & & & & & \\
\hline \multirow{2}{*}{ Development } & Human (2) & Seed & Baby & Child & \multirow{2}{*}{6} & \multirow{2}{*}{4} \\
\hline & Tree & & & & & \\
\hline Limitlessness & Sea & Universe & & & 2 & 1.33 \\
\hline Total & & & & & 150 & 100 \\
\hline
\end{tabular}


It was determined that the metaphors under the tool / vehicle category were remote control (2), means of transport (2), food processor (2), plane (2), walking stick, stairs, etc. metaphors. It is observed that another one of the categories including the metaphors indicated by PTTs in Table 3 is the requirement category. It was determined that the water (11) metaphor was mostly produced for the requirement category. Furthermore, the metaphors such as air (2), hand (2), chocolate (2), brain (2), salt (2), and heart (2) were also included in this category.

While the pencil (4) and book (3) metaphors were mostly used for the permanence category, it was observed that the metaphors such as clothes peg, nail, body language, ink, and television were also produced.

It was determined that the change category included the metaphors such as time (2), galaxy, tree, and chameleon and that the attractiveness category included the metaphors such as appetizer (2), rainbow, love, and flower.

The metaphor that was mostly produced for the process category, which is another category, is the road (3) metaphor. Apart from this, it was determined that the tree, soil, chain and stairs metaphors were also used. It was determined that the human (2), seed, baby, child and tree metaphors were produced for the development category, and the sea and universe metaphors were produced under the limitlessness category. The examples for the specified metaphors in each category are presented below:

"Instructional technology is like a guide because it tells us what is going on where we go." (PTT 14)
"Instructional technology is like a ship because it takes us where we want to go in an endless sea like knowledge." (PTT 56)

"Instructional technology is like a computer because it is an indispensable requirement now." (РTT 55)

"Instructional technology is like a refrigerator because, just as the refrigerator keeps the food fresh, instructional technology also ensures that information is kept fresh in people's brains." (PTT 90)

"Instructional technology is like time because it is in a constant change according to conditions." (PTT 147)

"Instructional technology is like love because love allows you to be interested in someone who is alone in the crowds, instructional technology also enables to focus only on what is told in the sea of knowledge." (PTT 108)

"Instructional technology is like a process because it is a process like the water that goes to the leaf of the tree from its root." (PTT 52)

"Instructional technology is like a human because it improves as it realizes itself." (PTT 126)

"Instructional technology is like the universe because it has no limits." (PTT 9)

\subsection{Findings for the Concept of Teaching Material}

The metaphors produced by PTTs for teaching material were examined in terms of having positive and negative qualities in terms of meaning, and the results are presented in Table 4.

Table 4. Distribution of the Metaphors of PTTs for the Concept of Teaching Material

\begin{tabular}{|c|c|c|c|c|c|}
\hline Category & & Name of Metaphor & & & Tota \\
\hline \multirow{20}{*}{$\begin{array}{c}\text { POSITIVE } \\
\text { METAPHORS }\end{array}$} & Water (9) & Sun (2) & Savior & Dollar & \multirow{20}{*}{146} \\
\hline & Air (7) & Navigation (2) & Pole Star & Salad & \\
\hline & Book (6) & Auxiliary (2) & Model & Blackboard & \\
\hline & Key (5) & Walking stick (2) & Support force & Magic wand & \\
\hline & Bread (5) & Vein (2) & Torch & Weapon & \\
\hline & Toy (5) & Sky & Fruit & Slideshow & \\
\hline & Drug (5) & Rope & Motor & Brain & \\
\hline & Writing (4) & Map & Colored pencil & Watermill & \\
\hline & Road (4) & Language & Arrow & Dessert & \\
\hline & Game (4) & Fluorescent Lamp & Fishing rod & Telescope & \\
\hline & Road sign (3) & Rainbow & Automobile & Fertilizer & \\
\hline & Lighthouse (3) & Engineering vehicle & Apple & Column & \\
\hline & Jigsaw (3) & Lever & Play dough & Glasses & \\
\hline & Teacher (3) & Plane tree & Steel & Notebook & \\
\hline & Stairs (3) & Spoon & Lantern & Meal & \\
\hline & Light (3) & Cream on the cake & Board & Stars & \\
\hline & Pencil (3) & Tree & Daisy & Crossword & \\
\hline & Salt (3) & User guide & Piano & Bridge & \\
\hline & Clock (3) & Electronic devices & Compass & Assistant & \\
\hline & Spice (2) & Illustrated children's book & & & \\
\hline $\begin{array}{c}\text { NEGATIVE } \\
\text { METAPHORS } \\
\end{array}$ & Butterfly & Turtle & Money & Brick & 4 \\
\hline Total & & & & & 150 \\
\hline
\end{tabular}


As it is seen in Table 4, it was determined that 146 (97\%) of 150 PTTs used metaphors with positive connotations in terms of meaning, and 4 PTTs produced metaphors that could be considered as negative. One of the PTTs who produced a negative metaphor wrote the statement of "Teaching material is like a turtle because it is a slowpoke, it does not draw attention to itself." (PTT 10). Another one used a negative metaphor by stating that "Teaching material is like a brick because we carry it like a porter." (PTT 33).

When the metaphors that were described as positive were examined, it was determined that the most commonly used metaphors were water (9), air (7), book (6), key (5), bread (5), toy (5), and drug (5). The examples of metaphors with positive connotations are as follows:
"Teaching material is like water because it is like drinking water when a person is chocked up. Materials refresh the course when it becomes boring." (PTT 60)

"Teaching material is like air because we always need it." (PTT 11)

"Teaching material is like a book because it provides information about the subject." (PTT 105)

"Teaching material is like a key because it opens the door to new horizons." (PTT 75)

"Teaching material is like bread because there is no satisfaction in the course without material." (PTT 97)

"Teaching material is like a toy because it makes teaching enjoyable." (PTT 62)

"Teaching material is like a drug because it is effective in a short time and lasting." (PTT 85)

Table 5. Distribution of the Metaphors of PTTs for Teaching Material by Categories

\begin{tabular}{|c|c|c|c|c|c|}
\hline Category & & Metaphor & & $\mathbf{f}$ & $\%$ \\
\hline \multirow{11}{*}{ Tool/Vehicle } & Key (5) & Map & Motor & \multirow{12}{*}{47} & \multirow{12}{*}{31.34} \\
\hline & Road (3) & Spoon & Weapon & & \\
\hline & Stairs (3) & Rope & Arrow & & \\
\hline & Jigsaw (3) & Telescope & User guide & & \\
\hline & Auxiliary (2) & Column & Automobile & & \\
\hline & Clock (2) & Engineering vehicle & Book & & \\
\hline & Walking stick (2) & Fishing rod & Magic wand & & \\
\hline & Vein & Support force & Pole Star & & \\
\hline & Language & Lever & Electronic devices & & \\
\hline & Bridge & Savior & Fertilizer & & \\
\hline & Watermill & Glasses & Assistant & & \\
\hline \multirow{11}{*}{$\begin{array}{c}\text { Informative/Information } \\
\text { Source }\end{array}$} & Brick & & & & \\
\hline & Water (9) & Daisy & Fruit & \multirow{5}{*}{38} & \multirow{5}{*}{25.33} \\
\hline & $\operatorname{Air}(7)$ & Plane tree & Meal & & \\
\hline & Bread (5) & Salad & Vein & & \\
\hline & Drug (5) & Clock & Blackboard & & \\
\hline & Salt (3) & Money & & & \\
\hline & Book (5) & Sun (2) & Fluorescent Lamp & \multirow{5}{*}{29} & \multirow{5}{*}{19.33} \\
\hline & Road sign (3) & Navigation (2) & Stars & & \\
\hline & Lighthouse (3) & Brain & Road & & \\
\hline & Teacher (3) & Compass & Lantern & & \\
\hline & Light (3) & Tree & Torch & & \\
\hline \multirow{6}{*}{ Attractiveness } & Toy (5) & Crossword & Apple & \multirow{6}{*}{25} & \multirow{6}{*}{16.67} \\
\hline & Game (4) & Illustrated children's book & Sky & & \\
\hline & Spice (2) & Cream on the cake & Slideshow & & \\
\hline & Rainbow & Dessert & Board & & \\
\hline & Play dough & Colored pencil & Piano & & \\
\hline & Turtle & Butterfly & & & \\
\hline \multirow{2}{*}{ Permanence } & Writing (4) & Dollar & Steel & \multirow{2}{*}{11} & \multirow{2}{*}{7.33} \\
\hline & Pencil (3) & Model & Notebook & & \\
\hline Total & & & & 150 & 100 \\
\hline
\end{tabular}


As it is seen in Table 5, 5 different categories were created for the concept of teaching material: These are tool / vehicle, requirement, informative / information source, attractiveness, and permanence. Among these categories, tool / vehicle is the category in which PTTs produced the most metaphors. It is observed that the key (5) metaphor was mostly used in this category, and it was followed by the road (3), stairs (3), and jigsaw (3) metaphors. It was determined that metaphors were produced mostly for the requirement category after the tool / vehicle category. In the requirement category, water (9) is the most commonly used metaphor. It was followed by the air (7), bread (6), drug (5), and salt (3) metaphors. The informative / information source category is in the third place with 29 metaphors. In this category, book (5) is the most commonly used metaphor. It was followed by the road sign (3), lighthouse (3), teacher (3) and light (3) metaphors. Another category created by the metaphors indicated by PTTs for teaching material is the attractiveness category. Toy (5) is the most commonly used metaphor of this category, and it is followed by the game (4) and spice (2) metaphors in terms of usage frequency. The last category created by the metaphors developed by PTTs for the concept of teaching material is the permanence category. In this category, writing (4) and pencil (3) are among the most commonly used metaphors. The examples of the specified metaphors in each category are presented below:

"Teaching material is like a telescope because the stars are already in the sky, but there is a need for a signifier." (PTT 74)

"Teaching material is like a teacher because he clarifies every subject that is not understood." (PTT 65)

"Teaching material is like a user guide because we read the user guide since we do not know how to use the new item we have bought." (PTT 40)

"Teaching material is like a rainbow because it draws attention to itself." (PTT 124)

"Teaching material is like writing because spoken words fly away, written words remain." (PTT 132)

\section{Discussion and Conclusions}

Within the scope of the study in which it was aimed to determine the perceptions of PTTs regarding the concepts of instructional technology and teaching material through metaphors, it was determined that the vast majority of PTTs produced metaphors with positive qualities in terms of meaning for the concept of instructional technology, and only two PTTs produced metaphors with negative qualities in terms of meaning. Similarly, Durukan, Hacioğlu \& Usta [25] determined in their study that pre-service teachers had a positive perspective on the concept of technology, and Zoller \& Ben-Chaim [38] determined that teachers had positive attitudes and beliefs towards working with a computer. On the other hand, in some studies [21, 23, 24], it was determined that pre-service teachers also used negative metaphors for technology. The attitudes of pre-service teachers or teachers towards instructional technology positively or negatively affect the integration of teaching processes with technology. Indeed, Bullock [39] stated that teachers' attitudes played a facilitating or complicating role in the adoption of technology. In this context, it has been determined that teachers with a positive attitude towards technology can easily include technology in the teaching process [40]. Teachers' beliefs regarding the fact that course objectives can be achieved more easily with the use of instructional technology in the teaching process may allow teachers to integrate instructional technology with their courses. In this context, in the study of Duman and Demir [41] carried out with pre-service Turkish and Turkish language and literature teachers and teachers of these courses, it was determined that the vast majority of the participants thought that computer-assisted instruction could achieve the objectives of the course more compared to the traditional teaching approach in the teaching of Turkish and literature.

In the present study, the metaphors of PTTs for the concept of instructional technology were classified under 9 categories. These categories are informative/information source, tool/vehicle, requirement, permanence, change, attractiveness, process, development, and limitlessness. Based on these findings, it can be said that the categories in which the metaphors of PTTs are classified are compatible with the definition and characteristics of the concept of instructional technology because instructional technology is the theories and applications based on designing, developing, using, managing and evaluating the processes and resources for learning [42].

Within the scope of the study, it was determined that PTTs mostly produced metaphors for the informative / information source category with respect to instructional technology. The fact that PTTs usually defined instructional technology as a source of knowledge acquisition with the metaphors such as a book, teacher, guide and mother or as informative with the metaphors such as a lantern, the Pole Star and the sun is important in terms of reflecting their positive perspectives on instructional technology. Since technological tools that enable easy access to all kinds of information also require the use of skills such as selecting, analyzing, evaluating and presenting information, as well as access to information, in the teaching process, it is possible that they were positively defined by most of the PTTs. It was determined that this finding of the study was similar to the result of the study carried out by Karakoyun [43], and pre-service visual arts teachers generally considered technology as the source of most information. In other studies in which pre-service teachers' perceptions of technology were examined [22, 24, 25], it was determined that the metaphors mentioned were evaluated under the category of a means to information or being an information 
source.

The metaphors of PTTs for instructional technology were mostly evaluated under the information source/informative category, and it was followed by the tool/vehicle and requirement categories. It was determined that PTTs, who perceived instructional technology as a tool/vehicle, indicated metaphors such as remote control, means of transport, food processor, plane, walking stick, and stairs. Under the requirement category, it was observed that instructional technology was perceived using the metaphors such as water, air, salt, hand, and brain. With respect to the concept of teaching material, it was determined that PTTs mostly produced metaphors for the tool/vehicle category and that it was followed by the categories of requirement and informative/information source.

The requirement category was also determined as a result of some studies that were carried out to determine pre-service teachers' perceptions of technology, and pre-service teachers generally associated technology with a requirement such as air and water [21, 23, 24, 25, 43, 44].

Within the scope of the study, other categories determined based on the metaphors indicated by PTTs are permanence, change, attractiveness, process, development, and limitlessness. In some studies in which pre-service teachers' general perceptions of technology were determined [23, 24, 43, 45], similarly, the metaphors that could be evaluated under the categories of limitlessness, change, and development were also used.

Based on the findings obtained and by taking into account the metaphors produced by PTTs, it can be said that they perceive the concept of instructional technology as a requirement, an informative / information source and a process with changeability in which it is not possible to draw boundaries in teaching, that is open for improvement, makes information permanent and can attract student's attention by various tools/vehicles.

The metaphors produced by PTTs for the concept of teaching material were grouped under the categories of tool/vehicle, requirement, informative/information source, attractiveness, and permanence. It was determined that PTTs mostly produced metaphors for the tool/vehicle category with respect to the teaching material, and it was followed by the categories of requirement, and informative/information source. In the study carried out by Eren \& Tekinarslan [31], the factors explaining pre-service teachers' metaphors related to the concepts of teacher, teaching, learning, teaching material and evaluation were examined and it was determined that one of the factors for teaching material was the teaching material as a tool, which supports this finding. The need for tools to be able to create teaching materials and therefore the organic bond between tool and material may have caused that pre-service teachers frequently produced metaphors that could be evaluated under the tool category while explaining the teaching material.
In the study, it was determined that there were 4 PTTs who produced negative metaphors for teaching material. One of the PTTs wrote the statement of "Teaching material is like a turtle because it is a slowpoke, it does not draw attention to itself." (PTT 10). Another one used a negative metaphor by stating that "Teaching material is like a brick because we carry it like a porter. " (PTT 33). Of these negative metaphors, turtle and butterfly are included in the attractiveness category, brick is included in the tool/vehicle category, and money is included in the requirement category. However, it is remarkable that this negative perception is very low, the vast majority of PTTs produced positive metaphors, and each of the categories in which the produced metaphors are classified has a characteristic to emphasize the importance of this concept in teaching. Indeed, it has been emphasized in the relevant literature $[46,47]$ that teaching materials help to meet the individual needs of students, attract attention by providing multiple learning environments, make learning permanent, provide the representation of consistent contents at different times, make it easier to understand the content by simplifying it and contribute to the development of vocabulary.

When the metaphors produced for teaching material are taken into account, it can be said that PTTs define this concept as an informative/information source, a tool/vehicle needed to attract attention for teaching and to ensure the permanence of knowledge.

The categories reached based on PTT's metaphors for the concepts of instructional technology and teaching material show similarities and differences from several aspects. Among the categories determined for the two concepts, it is observed that the categories of informative/information source, tool/vehicle, requirement, permanence and attractiveness are common. Despite this association, the categories of change, process, development and limitlessness were determined based on PTT's metaphors for the concept of instructional technology, and it was observed that these categories did not emerge for teaching material. It can be said that the main reason for this difference was due to the main difference between the characteristics of the two concepts and the correct perception of it by PTTs. The characteristics of being a process, developability for instructional technology that are included in the definition of Seels and Richey [9] also appear in the categories created based on the metaphors produced by PTTs. The development and changes based on needs in the process and the fact that this situation brings out unlimited variations in accordance with the requirements of the age and individual indicate that there is harmony between the definition of the concept and the metaphors produced by PTTs. The fact that teaching materials are attractiveness, permanent vehicle/tool of information source that can be designed by the needs similar to instructional technology is included in the categories of metaphors produced by PTTs 
for both concepts. The differences in metaphor categories for the two concepts reflect the correct perception of PTTs in line with the definition in the literature because the concept of teaching material covered by instructional technology, which is the name of the process, includes the contents of course presentations performed using tools to achieve the objectives [10]. The fact that instructional technology is the systematic design, implementation, and evaluation of the entire learning and teaching process in terms of specific objectives by using human and material resources together for more effective teaching which was stated by Reiser [8], is also consistent with the similarities and differences between the categories in the concept mapping of the metaphors produced by PTTs for the concept of instructional technology and teaching material. The fact that the categories of process, development, and change come to the forefront for instructional technology can be explained by the contribution of instructional technology to the design of the learning and teaching process, and the fact that this design, implementation, and evaluation contain a significant and unlimited development and change. In this context, it can be said that PTTs have grasped the nature and most basic characteristics of the concept of instructional technology and the reason for existence in terms of the learning-teaching process. While some of the metaphors developed by PTTs for the concept of instructional technology are evaluated under the categories of process and limitlessness, it can be said that the fact that the metaphors developed for the concept of teaching material do not have a characteristic associated with process and limitlessness causes that these concepts are perceived differently and exist with right connotations in the minds of some PTTs. Since instructional technology includes a systematic process such as designing, developing, using, managing and evaluating to make the learning and teaching environment effective, PTTs may have emphasized process and limitlessness while distinguishing this concept from teaching material.

The suggestions developed based on the findings obtained within the scope of the study are as follows:

Since metaphors are tools that help to understand the perceptions of the concepts, they can also play an important role in determining misconceptualizations. Since pre-service teachers' wrong or negative perceptions of the concepts can be reflected in their thoughts and behaviors, their perceptions of different concepts that are effective in the teaching process can be determined through metaphors. Thus, negative metaphors developed by pre-service teachers for important concepts can be determined, and their reasons can be investigated.

By considering the presence of PTTs producing negative metaphors for the concepts of instructional technology and teaching material, it is possible to raise awareness of why they need these concepts in the language teaching process, and studies aimed at changing the negative perspectives of pre-service teachers can be included more.
The further integration of the process of developing language skills with instructional technology is a necessity of our time. This requirement should also be reflected in teacher training programs, and it is necessary to place too much stress on the training of PTTs in a way that they have gained the ability to use instructional technology and design materials in their lessons. The quality of integration of the Turkish Lesson Curriculum with instructional technology in terms of acquisitions, content, the type of text read, methods and techniques, tools and materials, and assessment and evaluation studies should be reviewed. The acquisitions and activities that will lead Turkish teachers and students to design materials to develop language skills and to ensure that grammar is taught through implication should be included more in the Turkish Lesson Curriculum. PTTs should be informed theoretically and practically in terms of the philosophy of the Turkish Lesson Curriculum and its approach to language teaching, instructional technology, and material design in undergraduate courses they take.

This study was carried out with PTTs studying at Çukurova University Faculty of Education Turkish Education Department. Since the instructional technologies and material design course is taught in all departments of the faculties of education, the perceptions of pre-service teachers studying in other departments regarding the concepts of instructional technology and teaching material can be determined through metaphors, and the differences in their perceptions can be revealed.

Furthermore, in the studies to be carried out, the perceptions of Turkish teachers, who actively perform the language teaching process, regarding the concepts of instructional technology and teaching material, can be determined through metaphors based on the practices they perform in their classroom.

\section{REFERENCES}

[1] Woodward, T. Models and metaphors in language teacher training. Cambridge University Press, 1996.

[2] Yanpar, T. \& Yıldırım, S. Öğretim teknolojileri ve materyal geliştirme. Anı Yayıncılık, Ankara, 1999.

[3] Uşun, S. Özel öğretim teknolojileri ve materyal geliştirme. Pegema Yayınları, Ankara, 2000.

[4] Davis, N. Technology in teacher education in the USA: what makes for sustainable good practice? Technology, Pedagogy and Education. 12 (1), 59-73, 2003.

[5] YÖK. Eğitim Fakültesi Öğretmen Yetiştirme Lisans Programlar1. Ankara, 1998.

[6] Mackey, W. F. Language teaching analysis. Longmans, Green \& Co Ltd, London, 1969.

[7] Karademirci, A. H. Öğretim teknolojileri: tanımı ve tarihsel 
gelişimine yeniden bakmak. XII. Akademik Bilişim Konferans1 Bildirileri. 10-12 Şubat 2010, Muğla Üniversitesi, 2010.

[8] Reiser, R. Instructional technology: a history. In R. Gagné (Ed.). Instructional Technology: Foundations. Hillsdale. Lawrence Erlbaum Associates, 1987.

[9] Seels, B. \& Richey, R. C. Instructional technology: the definition and domains of the field. Association for Educational Communications and Technology. Washington DC, 1994

[10] Yanpar, T. Öğretim teknolojileri ve materyal tasarımı (7th ed.). An1 Yayınc1lık, Ankara, 2006.

[11] Lakoff, G. The contemporary theory of metaphor. In A. Ortony (Ed.). Metaphor and thought (2nd ed.) (202-251). Cambridge University Press, 1993.

[12] Kövecses, Z. Metaphor. Oxford University Press, New York, 2010.

[13] Lakoff, G. \& Johnson, M. Metaphors we live by. University of Chicago, Chicago, 1980.

[14] Lynch, H. L., \& Fisher-Ari, T. R. Metaphor as pedagogy in teacher education. Teaching and Teacher Education. 66, 195-203, 2017.

[15] Csorba, D. Metaphor in science education Implications for Teacher Education. Procedia - Social and Behavioral Sciences. 180, 765-773, 2015.

[16] Clandinin, D. J. Classroom practice: teacher images in action. Falmer Press, London, 1986.

[17] Pajak, E. F. Psychoanalysis, teaching, and supervision. Journal of Curriculum and Supervision. 1, 122-131, 1986.

[18] Moser, K. S. Metaphor analysis in psychology-method, theory, and fields of application. Forum: Qualitative Social Research [On-line journal], 1 (2), 2000.

[19] Kadunz, G. \& Straber, R. Image - metaphor - diagram: visualization in learning mathematics. Proceedings of the 28th Conference of the International Group for the Psychology of Mathematics Education. 4, 241-248, 2004.

[20] Erdoğan, T. \& Gök B. Sınıf öğretmeni adaylarının teknoloji kavramına ilişkin algılarının metafor çözümlenmesi yoluyla incelenmesi. 8th International Educational Technology Conference. 1071-1077, 2008.

[21] Gök, B. \& Erdoğan, T. Investigation of pre-service teachers' perceptions about concept of technology through metaphor analysis. The Turkish Online Journal of Educational Technology (TOJET). 9 (2), 145-160, 2010.

[22] Kurt, A. A. \& Özer, Ö. Metaphorical perceptions of technology: case of Anadolu University teacher training certificate program. Journal of Theory and Practice in Education. 9 (2), 94-112, 2013.

[23] Fidan, M. Prospective teachers' metaphoric perceptions regarding the concept of technology and social network. The Journal of Academic Social Science Studies (JASSS). 25 (1), 483-496, 2014.

[24] Korkmaz, F. \& Ünsal, S. An investigation of preschool teachers' perceptions on the concept of "technology".
Mustafa Kemal University Journal of Graduate School of Social Sciences. 13 (35), 194-212, 2016.

[25] Durukan, Ü. G., Hacioğlu, Y. \& Usta, N. D. Computer education and instructional technology prospective teachers' perceptions of technology. Journal of Computer and Education Research. 4 (7), 24-46, 2016.

[26] Çoklar, A. N. \& Bağcı, H. Öğretmen adaylarının eğitim teknolojisi kavramına yönelik geliştirmiş olduğu metaforlar. Journal of Qafqaz University. 28, 172-184, 2009.

[27] Bağc1, H. \& Çoklar, A.N. What are the roles of prospective teachers on the educational technology use: a metaphor study? World Journal on Educational Technology. 2 (3), 186-195, 2010.

[28] Şenyuva, E., \& Kaya, H. Metaphors for the internet used by nursing students in Turkey: a qualitative research. Eurasian Journal of Educational Research. 50, 87-106, 2013.

[29] Eren, F., Çelik, I. \& Aktürk, A. O. Ortaokul öğrencilerinin Facebook algısı: bir metafor analizi. Kastamonu Eğitim Dergisi, 22 (2), 635-648, 2014.

[30] Köseoğlu, P. An analysis of prospective teachers' perceptions concerning the concept of "social media" through metaphors. EURASIA Journal of Mathematics, Science and Technology Education. 14 (1), 45-52, 2018.

[31] Eren, A. \& Tekinarslan, E Öğretmen, öğretme, öğrenme, öğretim materyali ve değerlendirmeye ilişkin metaforlar: yapısal bir analiz. Gaziantep University Journal of Social Sciences. 12 (3), 443-467, 2013.

[32] Yıldırım, A. \& Şimșek, H. Sosyal Bilimlerde Nitel Araştırma Yöntemleri (5th ed.). Seçkin Yayıncılık, Ankara, 2005.

[33] Creswell, J. W. Research design: qualitative, quantitative and mixed methods approaches. Sage Publications, 2014.

[34] Gallagher, S., \& Schmicking, D. Handbook of phenomenology and cognitive science. Springer, Berlin, 2010.

[35] Saban, A. Öğretmen adaylarının öğrenci kavramına ilișkin sahip oldukları zihinsel imgeler. Türk Eğitim Bilimleri Dergisi. 7 (2), 281-326, 2009.

[36] Saban, A. Okula ilişkin metaforlar. Kuram ve Uygulamada Eğitim Yönetimi. 55, 459-496, 2008.

[37] Miles, M. B. \& Huberman, A. M. Qualitative data analysis: an expanded sourcebook (2nd ed.). Sage Publication, California, 1994.

[38] Zoller, U. \& Ben-Chaim, D. Computer inclination of students and their teachers in the context of computer literacy education. Journal of Computers in Mathematics and Science Teaching. 15 (4), 401-21, 1996.

[39] Bullock, D. Moving from theory to practice: an examination of the factors that pre-service teachers encounter as they attempt to gain experience teaching with technology during field placement experiences. Journal of Technology and Teacher Education. 12 (2), 211-224, 2004.

[40] Kersaint, G., Horton, B., Stohl, H. \& Garofalo, J. Technology beliefs and practices of mathematics education faculty. Journal of Technology and Teacher Education. 
11(4), 549-577, 2003.

[41] Duman, B. \& Demir, M. Tezsiz yüksek lisans Türk Dili ve Edebiyatı öğretmen adaylarını edebiyat derslerinde bilgisayara dayalı öğretim ve interneti kullanmaya dair görüşleri. Uluslar aras1 Eğitim Teknolojileri Sempozyumu. Bildiriler II, 1081-1087, Sakarya, 2004.

[42] Ely, D. Toward a philosophy of instructional technology: thirty years on. British Journal of Educational Technology. 30 (4), 305-315, 1999.

[43] Karakoyun, F. Visual arts pre-service teachers' metaphoric perceptions related to technology. International Journal of

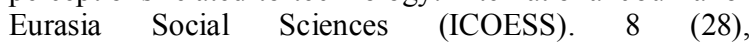
CXXIV-CXXXVIII, 2017.
[44] Kobak, M., \& Taşkın, N. R. Prospective teachers' perceptions of using technology in three different ways. Procedia - Social and Behavioral Sciences. 46, 3629-3636, 2012.

[45] Küçük, M. \& Yalçın, Y. Investigation of primary student teachers' perceptions about the concept of technology through metaphor. Paper presented at 10th Classroom Teachers and Education Symposium. Sivas / Turkey, 2011.

[46] Yalın, H. İ. Öğretim teknolojileri ve materyal geliştirme. Nobel Yayın Dağıtım, Ankara, 2002.

[47] Şimşek, N. Öğretmen ve öğretmen adayları için derste eğitim teknolojisi kullanımı. Nobel Yayın Dağııım, Ankara, 2002. 